UDK [323.283:28]:[32.019.5:004.738.5]

https://doi.org/10.18485/fb_ic4hs.2018.23

\title{
ADOPTING THE ISLAMIC STATE'S INTERNET PROPAGANDA METHOD: THE CASE OF BOKO HARAM
}

\author{
Tanja MILOŠEVIĆ*
}

\begin{abstract}
The Internet has provided terrorists with a perfect platform for spreading propaganda, not only through blog posts and social media, but also through posting various videos justifying their cause. The main topic of this research is the Internet propaganda of Boko Haram, the notorious Nigerian version of the Islamic State, and the way it resembles the propaganda of the Islamic State. Given the fact that the manner of spreading propaganda has changed in the era of the Internet, the actions of numerous currently active terrorist organizations have shifted into cyberspace. An analysis of this modern phenomenon is therefore of the greatest importance for combating contemporary terrorism. The Islamic State has provided the currently active terrorist groups with a perfect model for spreading terror on the Internet, which has been adopted by Boko Haram. Since the Islamic State has produced the most technologically advanced propaganda, it was to be expected that this model would be adopted by other terrorist organizations. This paper will thus present the modern means of spreading terrorist propaganda on the Internet, as well as some descriptive examples. The research was formulated as an analysis of information on the propaganda activity of the two most active terrorist organizations on the Internet, the Islamic State and Boko Haram, and an analysis of the propaganda material found on the Internet.
\end{abstract}

Keywords: Boko Haram, propaganda, terrorism, Islamic State, Internet.

\section{INTRODUCTION - TERRORISM AND INTERNET PROPAGANDA}

The Internet provides an unrestricted place where terrorist can easily create and spread propaganda through a limitless number of websites and social media platforms. As stated by Rieger, Frischlich and Bente (2013, p. 1), "extremist organisations chiefly use videos and online services on the Internet to win over supporters and to radicalize individuals".

The idea of propaganda is as old as mankind, but the means of spreading propaganda are constantly changing. According to Lieberman (2017, p. 98), propaganda has been documented throughout history. For example, the Greeks used the theatre, and Egyptian

\footnotetext{
* MA, Military Academy, University of Defense, Belgrade, Serbia, tanja.z.milosevic@gmail.com
} 
pharaohs used carvings on temple walls. These tactics are still present nowadays, but theatres and walls have been replaced by - cyberspace.

The main purpose of propaganda is still "to persuade the recipient into adopting the ideas the propagator tries to convey" (Rieger Frischlich, Bente; 2013, p. 1). Thus, studying the propaganda methods of currently active terrorist organizations is essential for the prevention of recruitment of new members and the spreading of fear in communities.

\section{BOKO HARAM}

The previous year has turned out to be one of the most violent years, as numerous terror attacks occurred in many countries. It should, however, be stressed that "the vast majority of deaths from terrorism occurred in one of five countries: Afghanistan, Iraq, Nigeria, Pakistan and Syria. And of these deaths, four groups were responsible for $74 \%$ of them: Boko Haram, The Taliban, ISIS and Al Qaeda" (Martin, 2017). Since terrorist organizations such as the Taliban and Al Qaeda need no introduction, as they have been present on the global terrorist map for decades, and ISIS being almost defeated ${ }^{1}$, the time has come to dedicate much-needed attention to the world's currently most vicious terrorist organization - Boko Haram.

Boko Haram was founded in 2002 by Mohammed Yusuf. At the beginning of the reign of this terrorist organization, its members were considered to be only "moderate revivalists attempting to implement social change" (Kane, 2007, pp. 64-67). However, when Shekau took over in 2009, Boko Haram gained prominence. It is said that Boko Haram has, since that time, killed tens of thousands and displaced about 2.6 million people from their homes (Onuoha, Oyewole; 2018, p. 2). This terrorist organization "was responsible for 6,644 deaths in 2014, an increase of $317 \%$ from the previous year, according to the Global Terrorism Index" (Pisa, Hume, 2015).

The significance of researching Boko Haram lies in the fact that "the jihadi insurgent movement Boko Haram has established itself as one of the relatively few jihadi movements to succeed in the capture, control, and governance of territory in Africa. Over the course of less than two decades, Boko Haram has morphed from a jihadi movement operating within Nigeria to a movement with a regional presence across multiple countries in West Africa and beyond" (Kassim, in: Zenn, 2018, p. 3).

Boko Haram ${ }^{2}$ has become notoriously famous worldwide since it started its raids on schools. The most famous case is the kidnapping of Chibok girls, when 276 teenage girls

${ }^{1}$ In December 2017, the Prime Minister of Iraq, Haider al-Abadi, declared victory against the Islamic State. However, in July 2018, reports emerged that the battle had shifted into the central zone of Iraq, as well that ISIS fighters were now using more nefarious tactics, thus spreading more fear among the local population. At this point, it is unclear how the situation will develop in the future (See also: Jay, 2018).

${ }^{2}$ The official name of this group is جماعة أهل السنة للاعوة و الجهاد (Jama'atu Ahlis Sunna Lidda'awati walJihad), meaning: People of the Sunnah (the practise and examples of Prophet Muhammad's life) for Preaching and Jihad Group. However, the Hausa-speaking residents in the north-eastern city of Maiduguri, where the group had its headquarters, dubbed it Boko Haram, meaning "Western education is a sin". 
were snatched from a boarding school in Borno State. Given that this organization has focused on female victims, it was to be expected that it would start using women for carrying out terrorist attacks. Moreover, the kidnapped girls were often used in propaganda materials, appearing in numerous videos. By February 28, 2018, records showed that 469 female suicide bombers had killed more than 1,200 people in Nigeria, Niger, Chad and Cameroon, injuring additional 3,000 people. Using female suicide bombers could also be viewed as ensuring publicity, which definitely has a propaganda effect. (Pearson, in: Zenn, 2018, p. 33-36).

\section{BOKO HARAM INTERNET PROPAGANDA}

Boko Haram is nowadays present on Facebook, Twitter, and especially Telegram as means of reaching the public with their statements (See also: Zenn, 2018, IV). Moreover, this organization has been publishing videos whose topics range from official statements, propaganda videos explaining the life of a common Boko Haram fighter, to threats and future plans announcements.

According to Mahmoud, (Mahmoud, in: Zenn, 2018, p. 88), messaging and propaganda tactics of Boko Haram can be divided into three phases. The first phase of Boko Haram propaganda was not propagating violence, and it was not spread via the Internet. This phase revolved around the leadership of Muhammad Yusuf, who mainly preached in mosques and appeared in local media. The sermons and interviews were all in Hausa and Kanuri languages, which only proves the fact that the main idea of his movement was the fight against Western influences.

Phase two started when Abubakr Shekau assumed leadership of Boko Haram, after Yusuf's death in 2009. From this point on, Boko Haram officially turned to violent actions. Also, the tactics completely changed under his rule: the main propaganda strategy was carried out through video messages, press statements, and fliers (Mahmoud, in: Zenn, 2018 , p. 88). By the end of 2013, the dynamics of Boko Haram's propaganda shifted to being largely based on video messages, while press statements and fliers were used only sporadically. Even though Shekau spoke mostly in the Hausa language, his speeches began including several Qur'anic recitations in Arabic, many of them the same as the ones used by Al-Qaeda.

The third phase started in May 2013, when the Nigerian government declared a state of emergency in Nigeria. During this period Shekau also pledged himself to Al-Baghdadi, the caliph of the Islamic State. At this point, Boko Haram's propaganda material started mirroring the material provided by the Islamic State. Also, at the beginning of 2015, Boko Haram set up a public Twitter account العروة الوثقى (Al- 'Urwa Al-Wutqha) in coordination with the Islamic State. Shekau's videos started appearing with Arabic subtitles, which suggests that they were meant not only for Nigerians, but for all Arabicspeaking Muslims worldwide. Moreover, as stated by Mahmoud, (Mahmoud, in: Zenn,

\footnotetext{
${ }^{3}$ The name of this media wing might have been chosen because this phrase means "the firmest bond" in Arabic. The work of this media wing of Boko Haram can be followed on this link: http://jihadintel.meforum.org/identifier/514/boko-haram-al-urwa-al-wuthqa
} 
2018, p. 103), after Shekau's pledge, the Islamic State-coordinated Media Office of the West Africa Province (MOWAP) took over Boko Haram's messaging. By the beginning of 2017, Boko Haram started putting Islamic State logos in the background of their videos, thus confirming that they still are strong supporters of this terrorist organization. Mahmood (2017, p. 21) observes that the 13 videos "produced by MOWAP after Boko Haram's admission into the Islamic State were markedly different from Shekau's previous messages. Short and direct, they exhibited high production values and often involved new members of the group unmasked on camera, diminishing Shekau's position as the public face of the group".

As stated by Mahmood (2017, p. 5), Boko Haram has been spreading its propaganda using the following tools: Twitter/Telegram (12\%), YouTube (14\%), jihadist forums and websites (6\%) and Press interviews and videos (68\%). Given that the idea of spreading videos on the ether has been adopted from the Islamic State, it is obvious that the impact of this terrorist organization is definitely strong in the case of Boko Haram.

\section{CONCLUSION}

Terrorism is a phenomenon that cannot yet be precisely defined because it changes over time. Moreover, it is clear that terrorist organizations are nowadays frequently present in cyberspace. Thus, keeping track of propaganda - and fighting against it, is an essential part of combatting contemporary terrorism.

The world has come a long way, almost defeating the Islamic State, but its influence on other terrorist organizations is still visible. It is obvious that the propaganda tactics of the Islamic State have been adopted by Boko Haram. This cooperation between Boko Haram and the Islamic State is primarily reflected in their adoption of video-making techniques and scenarios, as well as in the official support from the Islamic State public representatives. Even though Boko Haram has put its stamp on propaganda by introducing women into the terrorist battlefield, it is undeniable that the creation of high-tech videos, as well as the introduction of Arabic subtitles, suggests a strong cooperation between these two terrorist organizations. Moreover, the fact that Boko Haram's leader has abandoned the practice of spreading his word in the Hausa language opens up the possibility for the recruitment of not only Islamic State members, but also any other Muslim individuals prone to radicalization.

It is therefore obvious that, if the world wishes to put an end to Boko Haram, it is necessary to analyze the propaganda spread by these two organizations. Given that armed forces cannot exist without soldiers, the first step in combatting terrorism is the prevention of recruitment. Since fear is the sustenance of every terrorist organization, preventing propaganda from reaching the public might be the next step in beheading this African dragon. 


\section{REFERENCES}

Jay, M. (2018). Trump's got mother of all migraines coming on; ISIS is back in Iraq. Retrieved from: https://www.rt.com/op-ed/434364-isis-iraq-trump-syria/ (2018, July 27)

Kane, Ousmane. (2007). "Islamic Inroads in Sub-Saharan Africa," Harvard International Review 29:2.

Lieberman, Ariel Victoria. (2017). „NOTES - Terrorism, the Internet, and Propaganda: A deadly Combination“. Journal of National Security, Law and Policy, Vol. 9:95, 2017.

Mahmood, Omar S. (2017). „More that propaganda: A review of Boko Haram's public messages“. Institute for Security Studies, West Africa Report 20, March 20017.

Martin, Jenna. (2017). A closer look at 5 of the most dangerous terrorist groups on the planet. Retrieved from: https://www.sbs.com.au/guide/article/2017/06/13/closerlook-5-most-dangerous-terrorist-groups-planet; (2018, July 11).

Onuoha, Freedom C.; „Oyewole, Samuel. (2018). Anatomy of Boko Haram: The Rise and Decline of a Violent Group in Nigeria“. Al Jazeera Centre for Studies.

Pisa, Katie; Hume, Tim. (2015). Boko Haram overtakes ISIS as world's deadliest terror group, report says. Retrieved from: https://edition.cnn.com/2015/11/17/world/global-terror-report/; (2018, July 26).

Rieger, Diana; Frischlich, Lena; Bente, Gary. (2013). Propaganda 2.0: Psychological Effects of Right-Wing and Islamic Extremist Internet Videos. Wolters Kluwer, Luchterhand.

The Middle East Forum. (n.d.). Jihad Intel Presented by the Middle East Forum: Vital Intelligence on Islamic Terrorist Organizations. Retrieved from: http://jihadintel.meforum.org/identifier/514/boko-haram-al-urwa-al-wuthqa; (2018, July 27)

Zenn, Jacob. (2018). „Boko Haram Beyond the Headlines: Analyses of Africa's Endduring Insurgency“. Combatting Terrorism Center at West Point, United 